\title{
Effect of Kilning Temperature on Some Physico-Chemical Properties of Malt
}

\author{
Eden Leka Lencha ${ }^{1}$, Tibebe Solomon ${ }^{2}$ \\ ${ }^{1}$ Lecturer at Hawassa University, School of Nutrition, of Food Science and Technology \\ ${ }^{2}$ Hawassa University, School of Nutrition, of Food Science and Technology
}

\begin{abstract}
The character and the quality of the malt is affected during kilning. Mashing and wort quality is also affected during kilning of malt. Accordingly an experiment was conducted on the malt quality parameters for malts kilned in different temperature. In Ethiopia, there is high demand of quality malt for new emerging bear industries. Thus, this research aims to evaluate the effect of kilning temperature of selected barley variety Holker from Kulumusa research center Ethiopia. The kilning of germinated barley was performed at four different temperatures $\left(50^{\circ} \mathrm{C}\right.$, $70^{\circ} \mathrm{C}, 90^{\circ} \mathrm{C}$ and $110^{\circ} \mathrm{C}$ ) in order to produce four different malts. The experiment contained in combination of the four kilning temperatures laid out in complete randomized design with three replications. As a result, all investigated malt quality assessing parameters which includes the hot water extract, color, $\mathrm{pH}$, malting weight loss and the wort viscosity were significantly different among the different treatment temperatures. Malts treated with $50^{\circ} \mathrm{C}$ and $70^{\circ} \mathrm{C}$ gave good malt quality containing higher hot water extract $(79.7$ and $75.17 \%)$, a normal color $(2.32$ and 2.63), standard $\mathrm{pH}$ (6.53 and 5.99), acceptable malting weight loss (0.60 and 1.55) and appropriate wort viscosity (1.66 and $1.62 \mathrm{cp})$, respectively.
\end{abstract}

Keywords: Malt, Kilning, Temperature, Physico-Chemical, Barley

DOI: $10.7176 / \mathrm{FSQM} / 106-01$

Publication date:March $31^{\text {st }} 2021$

\section{Introduction}

Barley (Hordeum vulagre L.) is the most widely adapted cereal grain in the world. The annual world production reached over 141 million tons in 2016 (FAOSTAT, 2018). Barley is commonly used for malting as it has a threecelled aleuronic layer that ensures extensive and uniform breakdown of the starchy endosperm which is important in the production of good quality malt (Brennan et al., 1997). The malting quality of barley is very complex and is controlled by many genes and is strongly influenced by the environment (Fox et al., 2003). Due to the increasing beer consumption in the world, there is a high demand for quality malting barley (Sardana and Zhang, 2005).

There are three steps for malting procedure includes: steeping, germination and kilning. Kilning is heating of grain with increasing temperature regime above $50^{\circ} \mathrm{C}$ in order to obtain desired properties for the malt. The desired properties include enzyme survival, removal of moisture for stabilization, removal of raw flavours, development of malty flavours and colour (Bamforth, 2003). The kilning of malt is not simply a drying process but also a chemical process in which the character and quality of the malt are generated (Johnston, 1954). The reaction of sugars and amino acids induced by heating during the kilning process and wort boiling leads to the formation of melanoidins via the maillard reaction responsible for imparting colour to beer (Bamforth, 2003).

It was observed that malt processing like kilning temperatures can affect the quality of the malt and it also determines wort colour (Bamforth, 2006). The most important quality parameters for the malting industry include moisture content (3-5.8\%), PH of wort (5.6-5.9), plump kernels $(>2.5 \mathrm{~mm})$, protein content in the range of (9$11.5 \%)$, high diastatic power (200-300wk) and high malt extract i.e. based on EBC standard. Malting varieties are preferred by brewing industries since the hull forms a filter bed during wort filtration, although hull-less barley could be also employed in malting (Bhatty, 1999).

Thus the aim of the present work was to study focuses on effect of drying temperature of Holker barley variety from Kulumusa research center Ethiopia, on some Physico-chemical properties of malt. Consequently, this will support in solving the familiar quality problems pointed out usually by the local brewing industries.

\section{Materials and Methods}

\subsection{Sample Collection and Preparation}

The raw material for the production of malt is the malting barley. The selected barley variety i.e. (Holker) was taken from Assela malt factory, Asela (Kulumsa) Ethiopia. The sample was cleaned to separate the foreign matters, including dust and dirty, also broken and immature grains. Barley kernels (SB) were malted in the Hawassa University Food Microbiology Laboratory.

Steeping: Three $\mathrm{Kg}$ of barley kernels were steeped in nylon bags with appropriate amount of tap water, following the procedures of (Weston et al., 1993). The kernels were steeped for $12 \mathrm{hrs,} \mathrm{followed} \mathrm{by} 2$ hrs aeration, $8 \mathrm{hrs}$ steeping, $2 \mathrm{hrs}$ aeration, $12 \mathrm{hrs}$ steeping, $2 \mathrm{hrs}$ aeration and finally $10 \mathrm{hrs}$ steeping (a total of $48 \mathrm{hrs}$ ) at room 
temperature to reach moisture content of $42-44 \%$.

Germination: The steeped barley was spread in nylon bags and placed on plastic sheet lined with aluminum shelves and were allowed to germinate at room temperature (Weston et al., 1993). Known amount of distilled water were sprayed every $24 \mathrm{hrs}$ for three days using hand sprayer to maintain the relative humidity. On the fourth day i.e. $96 \mathrm{hrs}$, (when the length of the acrospires is $3 / 4$ of the length of the kernels), the germinated sample were transferred to drying oven for kilning.

Kilning: The germinated sample was kilned in time and temperature controlled drying oven. The original sample was divided in to four equal parts. Each sample were then dried in four different drying temperatures (i.e. $50^{\circ} \mathrm{c}, 70^{\circ} \mathrm{c}, 90^{\circ} \mathrm{c}$ and $110^{\circ} \mathrm{c}$ ) for $24 \mathrm{hrs}$ in order to obtain four different malt samples (M50, M70, M90 and M110 respectively).

\subsection{Experimental Design}

The experiment was made in complete randomized design (CRD). The different drying temperatures (i.e. $50^{\circ} \mathrm{c}$, $70^{\circ} \mathrm{c}, 90^{\circ} \mathrm{c}$ and $110^{\circ} \mathrm{c}$ ) were replicated and evaluated under the above experimental design. In this experimental design, the drying temperature was the independent variable and the quality parameters (i.e. hot water extract, malting weight loss, moisture content, Wort viscosity and Wort $\mathrm{PH}$ ) were the dependent variables.

\subsection{Grain Quality Analysis}

\subsubsection{Grain moisture content (GMC)}

The selected barley variety was cleaned and samples were weighed on analytical balance and oven-dried for $2 \mathrm{hrs}$ at $105^{\circ} \mathrm{C}$. Finally moisture loss during drying were calculated and expressed in percentage (AOAC, 1990). It was calculated as shown below:$\mathrm{MC}=(\mathrm{W} 2-\mathrm{W} 3 / \mathrm{W} 2-\mathrm{W} 1)^{*} 100 \quad$ Where:

- $\mathrm{MC}=$ moisture content of the grain

- $\mathrm{W} 1=$ weight of the container

- $\mathrm{W} 2=$ weight of the sample and container

- $\quad \mathrm{W} 3=$ weight of the sample and container after drying

2.3.2 Thousand kernel weight (TKW)

Sample of the selected barley variety was prepared and 500 kernels were counted, and then the 500 kernels were weighed and calculated as follows:

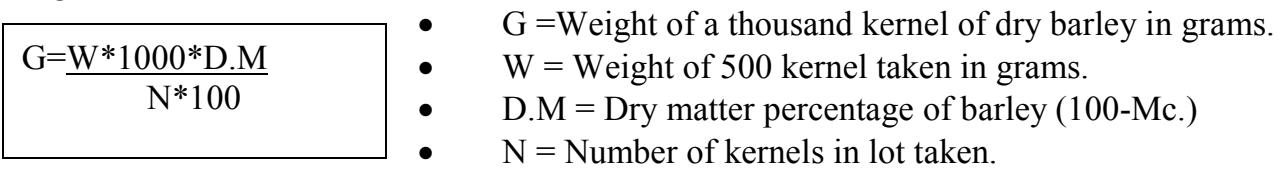

\subsection{Malt Quality Analysis}

2.4.1 Malt moisture content (MMC)

It was the same procedure used for grain moister content. The only difference being malt was used instead of barley grain.

2.4.2 Malting weight loss (MWL)

Malting weight losses of each sample were estimated by calculating as follow. Thousand kernel weight of the malt were subtracted from thousand kernel weight of the grain and divided to the thousand kernel weight of the grain. Then the result was multiplied by 100 .

$\mathrm{MWL}=((\mathrm{TKWG}-\mathrm{TKWM}) / \mathrm{TKWG}) * 100$

Thousand kernel weight of the sample was calculated with the same procedure used for the grain. The only difference being malt was used instead of barley grain.

2.4.3 Hot water extracts (HWE)

This was done as described in the AOAC (1990) method. 50g ground malt of each sample were mashed (mash bath), with appropriate amount of distilled water $(200 \mathrm{ml})$ at $45^{\circ} \mathrm{C}$ for $30 \mathrm{~min}$. Then the temperature was raised $\left(1{ }^{\circ} \mathrm{C} / \mathrm{min}\right)$ for 25 minute raising the temperature to $70^{\circ} \mathrm{C}$. This time a further $100 \mathrm{ml}$ of distilled water was added and saccharification was completed at this temperature marked by $2 \%$ iodine solution test.

The samples were cooled and adjusted to total mass by addition of distilled water. The samples were filtered through filter paper of diameter $320 \mathrm{~mm}$ and the time elapsed by each sample to filter fully into a flask were recorded as filtration time. The malt extract was determined by specific gravity method (DMA density meter) expressed in degrees Plato $(\mathrm{P})$ and converted to \% dry matter basis as follows:

$\mathrm{E}=\frac{(\mathrm{P}(\mathrm{MC}+800))}{(\mathrm{DM}(100-\mathrm{P}))} * 100$ 
Where:

- $\quad \mathrm{E}=\%$ extract on sample.

- $\quad$ D.M $=$ Dry mass of the malt.

- $\mathrm{P}=$ Grams of extract in 100g of Wort (Plato).

- $\mathrm{MC}=$ Moisture content of the malt.

2.4.4 Viscosity (v)

Viscosity of the Wort of each sample was measured using brookfield viscometer and were compared relative to water.

2.4.5 PH of Wort

The yield of extract is influenced by the $\mathrm{PH}$ of the mash and hence, consequently by the PH of the Wort. PH of the Wort of each sample was measured using a glass electrode.

\subsection{Data Analysis}

The experiment was done in triplicate times and the result was presented as mean plus or minus standard deviation. Analysis of Variance (ANOVA) was used to analyze data at $\mathrm{p}<0.05$ and the significance difference between means was determined by Fisher's LSD test. SAS, version 9.1 software was used to perform the statistical analysis.

\section{Result and Discussion}

\subsection{Barely Grain Quality Analysis}

From the different barely grain parameters for malting the two important ones for this study, thousand kernel weight and grain moisture content were assessed for the selected barley variety. The results for the assessed parameters are presented and discussed below.

\begin{tabular}{llc}
\multicolumn{2}{c}{ Table 1 Grain Quality Parameters } \\
\hline Parameters & GMC & GTKW \\
\hline Results & $12.57 \%$ & $41.44 \mathrm{~g}$ \\
\hline Where GMC = grain moisture content, GTKW= thousand kernel weight
\end{tabular}

\subsection{Grain Moisture Content}

The result from Table 1 indicates that the moisture content of the selected barley variety has fallen in the range of EBC standard i.e. $(10-13 \%)$ which is $(<14 \%)$ safe to store and for further germination. Different conditions may affect the moisture content of the samples such as absorption of moisture by the samples before it was transferred to desiccators to cool. From the result in Table 1 indicates the thousand kernel weight of the selected barley variety is greater than a specified range of EBC (European Brewery Convention) standard (35-40gm). Thousand kernel weights can be related to the kernel plumpness and the extract yield from malt barley studded by Kunze (1996). With an increase thousand kernel weight, the plumpness and extract yield can increase and the reverse is true. From the result obtained the kernel size (plumpness) and extract yield was good as compared to the EBC standard. The selected variety (Holker) showed higher thousand kernel weight value because of its larger kernel size.

Table 2. Effect of kilning temperature on some physicochemical properties of malt

\begin{tabular}{llllll}
\hline Treatment & HWE & Color & pH & MWL & W-viscosity \\
\hline $\mathrm{M} 50^{\circ} \mathrm{C}$ & $79.70 \pm 1.01^{\mathrm{a}}$ & $2.32 \pm 0.02^{\mathrm{d}}$ & $6.53 \pm 0.09^{\mathrm{a}}$ & $0.60 \pm 0.01^{\mathrm{d}}$ & $1.66 \pm 0.02^{\mathrm{a}}$ \\
$\mathrm{M} 70^{\circ} \mathrm{C}$ & $75.17 \pm 0.57^{\mathrm{b}}$ & $2.63 \pm 0.01^{\mathrm{c}}$ & $5.99 \pm 0.03^{\mathrm{b}}$ & $1.55 \pm 0.00^{\mathrm{c}}$ & $1.62 \pm 0.01^{\mathrm{b}}$ \\
$\mathrm{M} 90^{\circ} \mathrm{C}$ & $69.57 \pm 0.96^{\mathrm{c}}$ & $4.97 \pm 0.05^{\mathrm{b}}$ & $4.95 \pm 0.03^{\mathrm{c}}$ & $2.19 \pm 0.01^{\mathrm{b}}$ & $1.52 \pm 0.02^{\mathrm{c}}$ \\
$\mathrm{M} 110^{\circ} \mathrm{C}$ & $64.60 \pm 0.54^{\mathrm{d}}$ & $9.11 \pm 0.16^{\mathrm{a}}$ & $4.64 \pm 0.04^{\mathrm{d}}$ & $4.24 \pm 0.0^{\mathrm{a}}$ & $1.48 \pm 0.02^{\mathrm{d}}$ \\
\hline
\end{tabular}

Where: $\mathbf{H W E}=$ hot water extract, $\mathrm{MWH}=$ malting weight loss $\mathrm{W}$-Viscosity $=$ wort viscosities

The results in Table 2 showed that there is a significant difference in hot water extract among all different temperature treated barley malts as analyzed using analysis of variance at $(\mathrm{P}<0.05)$. Minimum hot water extract was obtained from barley malt sample $\mathrm{M} 110^{\circ} \mathrm{C}$ which is $64.60 \%$ and a maximum of it was obtained for malt sample $\mathrm{M} 50^{\circ} \mathrm{C}$ resulting in $79.70 \%$. Hot water extract (HWE) is one of the key quality attributes considered when determining the malting performance of barley. The international malting and brewing industries utilise standard procedures for measuring HWE, including European Brewery Convention (Analytica - EBC 1998). Good to brew barley varieties HWE falls in the range from $73.3 \%$ to $80.6 \%$ (Weston et al., 1993). The European Brewery Convention recommends that HWE of malt should in the range $79 \%$ to $82 \%$ (EBC 1998). According to this study the samples hot water extract from $\mathrm{M} 50^{\circ} \mathrm{C}$ meet the the European Brewery Convention (EBC, 1998). The lowest hot water extract was observed in both $\mathrm{M} 90^{\circ} \mathrm{C}$ and $\mathrm{M} 110^{\circ} \mathrm{C}$ samples $69.57 \%$ and $64.60 \%$, respectively (Table 2). This might be due to the applied high temperature which results in two types of common reactions known as caramelization and maillard reaction.

According to Table 2, there was significant difference at $(\mathrm{P}<0.05)$ for the wort color among all treatments, noticing that the color was read at the wave length of $430 \mathrm{~nm}$ and the results are in terms of absorbance. The 
maximum wort color (9.11) absorbtion was observed in malt sample $\mathrm{M} 110^{\circ} \mathrm{C}$ and the minimum (2.32) was observed for $\mathrm{M} 50^{\circ} \mathrm{C}$. According to EBC recommendation all treatments resulted in color of wort in standard range. Because the maximum absorbance is a standard for black beer while the minimum absorbance is a standard for light beer. It was observed that malt processing can have a large impact on colour development; increasing modification or kilning temperatures can lead to more intense wort colour (Bamforth, 2006). Increasing the kilning temperature increased the color of the wort (Table 2).

According to Table 2 there was significant difference in $\mathrm{pH}$ among all treatments at $(\mathrm{P}<0.05)$. Maximum $\mathrm{pH}$ of the wort was observed from malt sample $\mathrm{M} 50^{\circ} \mathrm{C}$ which is 6.53 and a minimum $\mathrm{pH}$ was observed in malt sample $\mathrm{M} 110^{\circ} \mathrm{C}$ resulting in 4.64. According to $\mathrm{EBC}$ standard $\mathrm{pH}$ of wort falls in a range (5.5-6.6). Therefore malt sample $\mathrm{M} 50^{\circ}$ and $\mathrm{M} 70^{\circ} \mathrm{C}$ were in the range of to EBC standard (EBC 1998).

As perceived in Table 2 there was a significant different in malting weight loss between the differing treating temperatures at $(\mathrm{P}<0.05)$. Minimum malting weight loss was obtained from malt sampl $\mathrm{M} 50^{\circ} \mathrm{C}$ which is $0.60 \%$ and a maximum of it was observed in $\mathrm{M} 110^{\circ} \mathrm{C}$ resulting in $4.24 \%$.

As shown in Table 2 that there was a significant difference $(\mathrm{P}<0.05)$ in the wort viscosities among all treatments. Viscosity was a measure of the "thickness" of the wort solution. It was expressed in centipoises units $(\mathrm{cP})$, a measure of the breakdown of beta-glucans. According to EBC 1998, the acceptable wort viscosity range $(1.55-1.65 \mathrm{cP})$. In this study wort viscosity of malt sample $\mathrm{M} 50^{\circ} \mathrm{C}$ and $\mathrm{M} 70^{\circ} \mathrm{C}$ are within the range of wort viscosity of EBS standard. Malts samples $\mathrm{M} 90^{\circ} \mathrm{C}$ and $\mathrm{M} 110^{\circ} \mathrm{C}$ showed a slight decline wort viscosity from the range of the standard. This may be due to milling effect and treatment in case kilning temperature difference. The higher the wort viscosity the longer it takes to filter and hence reduced the wort yields and the lower the wort viscosity would be the sign of poor malt quality.

\subsection{Conclusion}

This study clearly identified and investigated that there was difference in physico-chemical parameters between all barley based brewing malts treated in different temperature ranges. All evaluated malt quality assessing parameters showed a significant difference among all treatments, some values were found to be within the acceptable limit according to EBS standard. From different temperature ranges for malt treatment, malt treated with $50^{\circ} \mathrm{C}\left(\mathrm{M} 50{ }^{\circ} \mathrm{C}\right)$ and $70^{\circ} \mathrm{C}\left(\mathrm{M} 70{ }^{\circ} \mathrm{C}\right)$ showed a good malt quality: better hot water extract $(79.7 \%$ and $75.17 \%)$, color (2.32 and 2.63), pH (6.53 and 5.99), malting weight loss (0.60 and 1.55) and wort viscosity of (1.66 and 1.62) respectively. Generally, all investigated parameters hot water extract, color, $\mathrm{pH}$, malting weight loss and wort viscosity showed significant differences among all different kilning temperatures at $(\mathrm{P}<0.05)$.

\section{References}

AOAC. (1990). Official Methods of Analysis, 14th ed. Association of Official Analytical Chemists, Washington D.C.

Ashley, M., Christian, K., Russell, F. and Jim, I. Malting barley production in Michigan extension, Bulletin GMI035. New.

Bamforth, C. W. (2003). BEERS : Chemistry of Brewing A2 - Caballero, Benjamin. In Encyclopedia of Food Sciences and Nutrition -Second Edition (pp. 440-447). Oxford:

Bamforth, C. W. (2006). Brewing: New Technologies. Cambridge England: Woodhead Publishing Limited.Academic Press.

Bamforth, C., and A. Barclay. 1993. Malting technology and the uses of malt. Barley: chemistry and technology 297-354.

Barr, A.R., Coventry, S.J., Eglinton, J.K. and Mc Donald, G.K., 2003. The determinants and genome locations influencing grain weight and size in barley (HordeumvulgaraL.). Australian Journal of Agricultural Research 54:1103-1115.

Bendelow, V.M., LaBerge, D.E., 2000. Relationship among barley, malt and beer phenolics. Journal of the American Society of Brewing Chemists 37, 89-90.

Bhatty R.S. (1993): Nonmalting uses of barley. In: MacGregor A.W., Bhatty R.S. (eds.): Barley: Chemistry and technology. Amer. Assoc. Cereal Chem., St. Paul MN, USA: 335-380.

Brennan, C.S., Amor, M.A., Harris, N., Smith, D., Cantrell, I.,Griggs, D. and Shewryll, P.R., 1997. Cultivar differences in modification patterns of protein and carbohydrate reserves during malting of barley.

Briggs DE. 1998. Malts and malting. Blackie Academic \& Professional, London Barley. Barley Genetics Symposium, Barley Genetics. Garching. Munchen: Verlag Karl Thiemig.579-93.

Briggs, D.E., 2002. Malt modification - A century of evolving views.Journal of the Institute of Brewing 108 (4): 395-405.

Brown, A., Drum, F. and Lawrance, L. (2007) Australian Crop Report. Canberra: Australian Bureau of Agricultural and Resource Economics.

Burger, W.C. and D.E. LaBerge. 1985. Malting and brewing quality. Barley, Agronomy Monograph No. 26. ASA- 
CSSA-SSSA. Madison, Wisconsin. Pp. 367-402.

Chandra G. S., Proudlove, M. O. and Baxter, E.D. 1999. The structure of barley endosperm-an important determinant of malt modification. Journal of Science, Food and Agriculture 79: 37-46.

Chloupek O., Hrstkova P., Jurecka D. (2003): Tolerance of barley seed germination to cold- and drought-stress expressed as seed vigour. Plant Breeding, 122: 199-203.

Collins, H.M., Panozzo, J.F., Logue, S.J., Jefferies, S.P. and Barr, A.R., 2003. Mapping and validation of chromosome regions associated with high malt extract in barley (Hordeum vulgare L.) Aust J Agric Res; 54(12):1223-1240.

European Brewing Convention: Analytica (EBC) 1998. Method 4.5.1.

Euromalt, 2012. European organization, Annual statistics compendium of the barley, malt, beer supply chain. 2011 edition, p.58.

FAOSTAT (2018). Statistics Division of Food and Agriculture Organization of the United Nations. Retrieved from:

http://www.fao.org/faostat/en/\#data/QC. Accessed 2018 March 16.

Fastnaught, C.E., 2001. Barley fibre. In Cho, S., Dreher, M. (Eds.). “Handbook of Dietary Fiber”. Marcel Dekker, (New York) p. 519-542.

Fincher, G.B., and B.A. Stone, (1993. Physiology and biochemistry of germination in barley. In: MacGregor, A.W. and Bhatty, R.S. ed., Barley chemistry and technology. St Paul, Minnesota, pp. 247-295.

Fornal Ł., Filipowicz A. (2005). Ocena jakości jęczmienia browarnego [Quality assessment of malting barley].

Fox G.P., Panozzo, J.F., Li, C.D., Lance, R.C.M., Inkerman, P.A. and Henry, R.J., (2003).Molecular basis of barley quality. Austrailian Journal of Agricultural Research 54:1081-1101.

Gina E. (2008). Food for thought: The science and, culture and politics of food. Spring college seminar, 235.

Gomez, M. I., Obliana, A. B., Martin, D. F., Madzavamuse, M. and Monyo, E.S. (1997). Manual of Laboratory Procedures for Quality Evaluation of Sorghum and Pearl Millet. Technical Manual No. 2 ICRISAT, Patencheru 502, 324, Andhra Pradesh, India.

Jones, B. L (2005) Endoproteases of Barley and Malt. Journal of Cereal Science. 42, 139 - 156.

Johnston, J. H. St. (1954). Physical factors affecting the kilning of barley and malt. Journal of the Institute of Brewing, 6 0(4), 318-340. https://doi.org/10.1002/j.2050-0416.1954.tb02759.x

Kasha, K.J., Falk, D.E., and Ziauddin, A. (1993). Potential improvement of barley quality through genetic engineering. In: MacGregor, A.W. and Bhatty, R.S. ed., Barley chemistry and technology. St Paul, MN, USA, American Association of Cereal Chemists, 419-435.

Koning, R., 2006. Plant biology: Seeds and seed germination.

Kunze, W. 1996. Malt production. Pages 88-167 in: Technology, Brewing and Malting.

Versuchs und Lehranstalt für Brauerei, Berlin

L.O. Eneje, F.J.C. Odibo and Nwani C.D. (2012). Diastatic power and hot water extract development during malting. World journal of dairy and food science 7(2): 181-184.

Langridge, P. and Barr, A.R. (2003). Better barley faster: the role of marker assisted selection - Preface. Aust J Agricultural Res 54:1-4

Makeri, M.U., Nhama, I. and Badau, M.H, (2013). Physiochemical, malting and biochemical properties of some improved Nigerian barley cultivars and their malts, International food research journal, 20(4): 1563-1568.

Munck, L. and Møller, B. (2004). A new germinative classification model of barley for prediction of malt quality amplified by a near infrared transmission spectroscopy calibration for vigor "on line". Journal of the Institute of Brewing 110 (1): 3-17.

Newman, C.W. and Newman, R.K. (2006). A brief history of barley foods. Cereal Foods $\quad$ World 51, 4-7.

Nilan, R. A., and Ullrich, S. E. (1993).Barley: taxonomy, origin, distribution, production, genetics, and breeding. Ch. 1 in Barley chemistry und technology. MacGregor, A.W.,andBhatty.R.S(Eds).P.1-30. American of cereal chemists.Inc.st.paul.MN.

Palmer, G., Marie, S., Tedi, M. and Mike, C. (2001). Introductory guide to malting barley, the home-grown cereals authority (HGCA).

Reinikainen, P., Hirvonen, J., Jaakkola, N. and Olkku, J. (1996). Image processing of halved kernels in the control of malting and malt quality. Journal of the American Society of Brewing Chemists 53 (1): 26-28.

Riss P., Bang-Olsen K. (1991): Germination profile - A new term in malting barley analysis. In: Proceedings $23 \mathrm{rd}$ European Brewery Convention. Lisabon: 100-108.

Sardana, V. and Zhang, G.P. (2005). Effect of time of nitrogen application on the growth and yield of two barley (HordeumvulgareL.) cultivars.

Wang, J. (2005). Malting barley: situation and outlook. Agriculture and Agri-Food Canada Publications: Biweekly Bulletin. AAFC No. 2081/E. Vol 18(4).

Weston DT, Horsley RD Schwarz PB, Goos RJ. ((1993). Nitrogen and planting date effects on low protein spring barley. Agron. J. 85:1170-1174. 
Woonton B., Jacobsen J.V., Sherkat F., Stuart I.M. (2005): Changes in germination and malting quality during storage of barley. Journal of the Institute of Brewing, 111: 33-41.

\section{BIOGRAPHIES}

The Mrs Eden Leka was born on May 20, 1984, in Wolita Zone in SNNPR. She attended her primary education at Hombo Tabela Primary School and secondary education at Sodo Senior Secondary School. Following the completion of her secondary education, she joined Bahir Dar University, of Science Faculty in 2003 to purse her tertiary education and graduated with B.ED degree in Chemistry in June 2005. Right after graduation she was employed by Ministry of Education and served as chemistry teacher from October 2005. In July 2009, she joined the school of graduate studies of Haramaya University to purse studies leading to Master of Science degree in Food Science and Technology in the summer in-Service M.Sc program of the University. Currently she is lecturer at Hawassa University in the school of Nutrition Food science and Technology science 2014. 